\title{
Development of tobacco control in Lithuania and changes in indicators related to tobacco use
}

\author{
Laura Miščikienė, Justina Vaitkevičiūtè \\ Faculty of Public Health, Lithuanian University of Health Sciences, Lithuania
}

\begin{abstract}
In the early 1990s Lithuania had a high smoking prevalence among men and relatively low rates among women. The prevalence reached its peak in 2000. Thereafter, smoking rates declined, until recent years, when the smoking rates stagnated. In order to manage the harmful impact on society, tobacco policy changes were introduced in 1995 in the form the "Law on Control of Tobacco, Tobacco Products, and Related Products".
\end{abstract}

KEY WORDS: tobacco control, Lithuania, changes.

ADDRESS FOR CORRESPONDENCE: Laura Miščikienè, Faculty of Public Health, Lithuanian University of Health Sciences, Lithuania, e-mail: laura.miscikiene@lsmuni.lt

\section{TOBACCO CONTROL POLICY CHANGES}

After regaining independence in 1990, Lithuania’s most significant tobacco control achievement was the adoption of the Lithuanian Tobacco Control Law ("the Law") in 1995. The Law addressed tobacco and its products, both direct and indirect advertising, sponsorship, and tobacco control. Its purpose was to reduce the consumption of tobacco products and their harmful effects on human health. The Law aimed to protect the right to a tobacco-free environment, reduce accessibility of tobacco products, prohibit support for the tobacco industry with state or municipal funds, prohibit tobacco advertising, increase public awareness of the harm inflicted on human health by tobacco consumption, and encourage smokers to quit [1].

In its early stages, the Law included a number of bans to ensure better tobacco control. Specifically, it introduced:

1. Bans on the marketing of tobacco products without warning labels explaining the negative health effects of smoking. Health warnings were used in the period 1994-1997 without any official regulation. They were very small, and no rotation was required.

2. A ban on the sale of tobacco products to persons under the age of 18 years, as one of the keys to reducing accessibility of tobacco for minors.

3. Bans on the marketing of tobacco products in health care and educational establishments, and in market places dealing in children's and adolescent's goods only.

4. Ban on cigarette vending machines.

5. The provision that tobacco is subject of excise taxation.

6. Ban on smoking in all enclosed workplaces, with the recommendation to design special rooms for smoking.

7. Ban on smoking in educational, health, government and cultural institutions, and public transport.

8. A requirement for hotels and cafes to provide places for non-smokers.

9. A right for municipal governments to prohibit smoking in other public places.

10. Ban on smoking for uniformed officials in public places (excluding special rooms) [1].

11. Ban on tobacco advertising (also indirect advertising) on television, in print media, radio, cinema, the Internet, and outdoor billboards. However, the ban on advertising was not enforced fully, because some members of the Lithuanian parliament appealed against this article of the Law to the Constitutional Court. In 1997 the Court made the decision that this article of the Law was not unconstitutional. In 2000 a complete ban on tobacco advertising came into force [2].

It is worth adding that during the first years of independence in Lithuania significant differences in smoking 
rates between men and women were observed. In 1994 the proportion of daily smokers among Lithuanian men was 44\%, and among women - just 7\% [3]. In 1995 daily smoking at the age of 13 or younger was $8 \%$ [4]. Such indicators were related to the cultural context, because smoking was socially unacceptable for women. Thus, the tobacco industry that entered the Lithuanian market had two key target groups - women and young people. Marketing campaigns have been effective and smoking among women became increasingly acceptable. Despite the newly adopted Law, the prevalence of smoking in Lithuania grew rapidly and reached its peak in 2000. According to the Health Behaviour Monitoring Survey, the proportion of men aged 20-64 years smoking every day reached $52 \%$, and the proportion of smoking women of the same age reached 16\% [3]. Despite the decline in smoking prevalence between 2000 and 2002 [3], it was clear that new tobacco control measures were necessary in order to protect public health.

In 2004 Lithuania became a member of the European Union (EU) and ratified the World Health Organization (WHO) Framework Convention for Tobacco Control. Subsequently, the Lithuanian Tobacco Control Law was changed in compliance with EU legal acts. The new provisions provided revised definitions and their list was introduced; the list of principles of tobacco control policy was extended. The law stated that part of the budged funds received from the production, import, and trade of tobacco products must be assigned to the preparation and implementation of health prevention programs, including social advertising and promotion of non-smoking through mass media. Because of the lack of further regulation, the mentioned principle was not implemented. The updated Law also defined the general requirements for the composition and quality of tobacco products, introduced packaging requirements, forbidding misleading labelling (e.g. 'light'), prohibited the manufacture and/or selling of toys, food products, and other goods the design of which imitates tobacco products, and banned the purchase or transfer of tobacco products to persons under 18 years of age. The list of places where tobacco products cannot be sold was extended to include, for example, Internet cafes. However, smoking remained permitted in cafes and restaurants, although with significant restrictions (separate facilities [areas] for smokers, a requirement that customers and workers be protected from tobacco smoke) [5]. Unfortunately, despite the adoption of measures introduced in 2004 on tobacco control, there was little change in smoking rates in 2004-2006 [3, 6]. Further legislative action was needed, and another significant amendment to the Law was adopted in 2006 and came into force in 2007, extending the complete ban on smoking to restaurants, cafes, and bars [7].

Klumbiene et al. evaluated the association between tobacco control policies and trends in smoking cessa- tion in 1994-2010 and determined that improvement in Lithuania tobacco control policies were associated with an increase in smoking cessation in the long-term perspective, especially among younger people [8]. However, after the introduction of these restrictions for an extended period of time, no further amendments to the Lithuanian Tobacco Control Law have been introduced. Nonetheless, the economic crisis, which coincided with an increase in tobacco excise tax in Lithuania, has contributed to further changes in tobacco consumption. In 2008 , the price of tobacco products increased by about $22 \%$ compared to 2007. In 2009 and 2010 the price was increased by $26 \%$ each year, resulting in a total price increase of approximately $48 \%$ between 2007 and 2010 [6]. This was accompanied by a decrease in consumption of legal tobacco products per capita and a decrease in the proportion of daily smokers in 2008 [3, 6]. However, since 2011 a worrying trend has been observed in Lithuania, as tobacco consumption has been increasing [6].

Moreover, new challenges such as the introduction of e-cigarettes have emerged since. In 2014 as many as $9 \%$ of Lithuanians tried to use e-cigarettes once or twice [9]; in 2017 this proportion increased to $11 \%$ [10]; Eurobarometer data show that in 2017 e-cigarette users were predominantly men, aged 35-39 years, and less well educated. The most frequently indicated reason for taking up e-cigarettes was to stop or reduce tobacco consumption (66\%). However, the majority of smokers and former smokers who use, or have used, e-cigarettes said that these devices did not help them reduce their tobacco consumption at all [10].

In 2014 further amendments to the Tobacco Control Law were adopted with the purpose of incorporating the provisions of the EU Directive [11]. The new amendments regulate the restrictions in sales of electronic cigarettes and refillable containers to minors, and their sale to persons under 18 years old was prohibited. They also ban the use of e-cigarettes and the possession of such devices for persons under 18 years of age. The nicotine content of e-liquid must be less than or equal to $20 \mathrm{mg} / \mathrm{ml}$, single-use e-cigarettes as well as e-cigarette tanks must not exceed $2 \mathrm{ml}$, and the volume of refill bottles must not exceed $10 \mathrm{ml}$. In addition, certain additives for e-liquids are banned, and only high-quality ingredients are allowed in their manufacture. E-cigarettes and refill containers must be child- and tamper-proof, protected against breakage and leakage, and have a mechanism that ensures filling without leakage. Finally, e-cigarette product packaging must contain health warnings and constituent information as specified in the Law [12]. The same amendments also changed the name of the legislation to "Tobacco, Tobacco Products, and Related Products Control Law”. Therefore, since 2015, e-cigarettes are subject to the same regulation as other tobacco products.

According to the World Health Organisation, keeping homes and workplaces free from second-hand 
smoke is an effective way of reducing cancer risk [13]. In 2015 , seeking better protection for the most vulnerable groups in society, an amendment of the Lithuanian Law on Control of Tobacco, Tobacco Products, and Related Products was introduced prohibiting smoking inside vehicles with passengers under the age of 18 years and/ or pregnant women. However, the enforcement of this provision is questionable, and it is difficult to evaluate the effectiveness of the new regulation due to poor data availability. The same applies to the latest plans to implement a ban on smoking on balconies of apartments. The proposal has thus far received negative assessments and resistance from the public because it considered an invasion of privacy; law enforcement is also doubtful about its successful implementation $[13,14]$.

Fiscal measures (e.g. excise taxation) are a proven 'best buy' policy to reduce the prevalence of smoking. Active excise taxation increases on tobacco products began in 2014 and continued in 2015, 2016, and 2017. The latest increase came in to force in March 2019.

In summary, Lithuania made many significant steps in tobacco control, and current regulation is rather strict compared to the Law introduced in 1995 . However, not all new measures seem feasible for implementation and enforcement, municipalities are not using the right to apply more stringent provisions of the legislation, and clearer national regulation is needed.

\section{CHANGES IN TOBACCO CONSUMPTION AND THEIR IMPACT ON HEALTH AND HEALTHCARE IN LITHUANIA}

As mentioned before, the smoking prevalence in Lithuania has changed significantly since 1990 . The proportion of daily smokers among the Lithuanian population was increasing until 2000, but after that a decrease was observed among men, and stagnation among women until 2014. In 2014 the proportion of daily smokers among men was $33 \%$, and among women it was $12 \%$ [3].

According to a study by the Lithuanian Drug, Tobacco, and Alcohol Control Department (hereafter NTAKD), the last-month prevalence (LMP) of smoking decreased by $2.2 \%$ between 2012 and 2016, from $36.1 \%$ to $33.9 \%$. This change was due to a significant decrease in the percentage of women who had smoked in the last 30 days. The rates of smoking remained highest among young women compared to older women. Nevertheless, the LMP of smoking among 15-34-year-old women also decreased from $28.9 \%$ in 2004 to $22.8 \%$ in 2016 . Smoking is still widespread among men in Lithuania. The LMP of smoking among men aged 15-64 years was $48.6 \%$ in 2004 and slightly increased in 2016 to $49.2 \%$. In 2016 the highest rates of LMP of smoking was among $35-64$-year-old men, at $52.9 \%$ (in 2004 it was $50.7 \%$ ). The decrease was observed in the 15-34-year-old age group, from $45.9 \%$ in 2004 to $43.7 \%$ in 2016 [19].
Inequalities among tobacco smokers were observed. According to a study by NTAKD, smoking was more common among men, people with secondary or higher education, and unskilled workers [19]. More specifically, daily smoking was more prevalent among respondents with higher or secondary education compared to respondents with university education [3]. Since 2000 the proportion of men smoking every day decreased in all education groups, but the differences between education groups remained the same. In 2014 daily smoking among men with secondary education was $39 \%$, and among men with university education it was $26 \%$ [3]. The proportion of daily smokers among women with a university degree continued to decline, while the proportion in the lower education group remained almost unchanged. In $20149 \%$ of women with a university education were daily smokers, as well as $17 \%$ of women with secondary education [3]. The Health Interview Survey of the Population of Lithuania 2014 identified that smoking among people living in rural areas was more prevalent compared to people living in urban areas [20].

In the year 2000 legal tobacco consumption per person aged 15 years and older stood at 1669 cigarettes and was at one of the highest levels historically in Lithuania. By 2017 rates decreased by $28 \%$. In the post- 2000 period the lowest amount of tobacco products sold by retail trade and catering enterprises was observed in 2010 (930 cigarettes). Similar trends were observed in consumption per capita [6]. This could be related to the economic crisis and the new excise taxes. However, it is very important to also take into account the use of unrecorded tobacco when assessing the total consumption of tobacco products. Unfortunately, there is still a lack of objective research on trends in unrecorded consumption.

Despite the fact that the sale of tobacco products to persons under the age of 18 years is prohibited, the European School Survey Project on Alcohol and Other Drugs (ESPAD) results show that lifetime prevalence of cigarette use among Lithuanian 15-16-year-old teenagers did not change during the 1995-2015 period and was one of the highest in Europe in 2015. In 2015 the prevalence of 15-16-year-old teenagers' lifetime use was $65 \%$, and cigarette use in the last 30 days was $24 \%$. Daily smoking prevalence among students aged of 13 years or younger in 2015 was $7 \%$ (9\% among boys and 5\% among girls) (Fig. 1) [15]. According to the Health Behaviour in School-aged Children (HBSC) study in 2013/2014, the proportion of 13-years-olds who smoke at least once a week was $10 \%$ among boys and $4 \%$ among girls (sixth place out of 42 participating countries). Smoking at least once a week among 15 -year-old boys stood at $20 \%$, and among girls at $12 \%$ (ninth place out of 42 participating countries) [21]. For comparison, in 1993/1994 only $0.2 \%$ of girls and $3 \%$ of boys aged 13 years smoked cigarettes once a week or more (the lowest among participating 


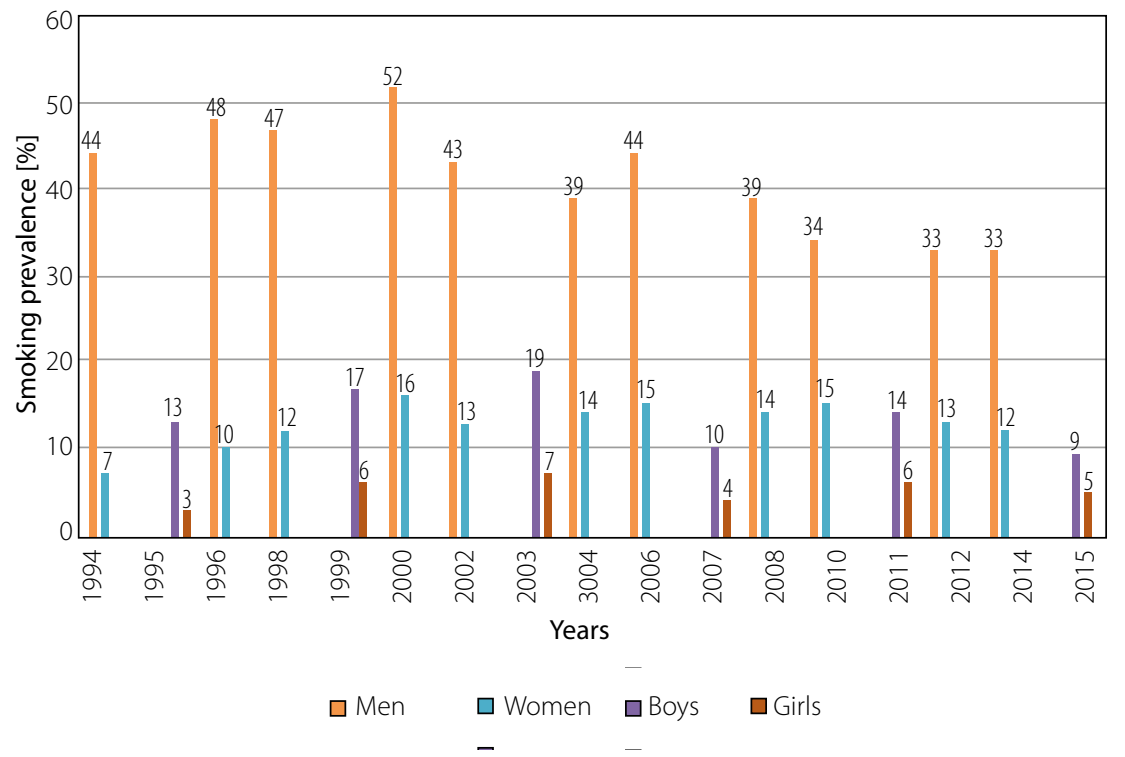

FIG. 1. Proportion of daily smokers among the Lithuanian population in 1994-2014 [3] and daily smoking at the age of 13 years or younger in 1995-2015 [15-18]. Data from the ESPAD and Health Behaviour among Lithuanian Adult Population surveys

countries). Also in 1994/1994 the prevalence among 15 -years-old was $4 \%$ among girls and $15 \%$ among boys (the lowest among participating countries) [22].

Liutkute et al. (2017) analysed the burden of smoking in Lithuania and identified that in 2013 13.9\% of total mortality in Lithuania could be attributed to smoking. Smoking was causing one out of seven deaths - one out of 35 among women and one out of four among men. The two main smoking-attributed diseases identified were ischaemic heart disease and lung cancer. These two diseases accounted for $67.8 \%$ of all smoking-attributed mortality. Respiratory diseases caused $17.7 \%$ of smoking attributed mortality [23].

Smoking usually causes diseases of the circulatory and respiratory system. In 2000-2017, a constant increase in the number of new cases of diseases of the circulatory system was observed. In 2017, the indicator was three times higher than in 2000 (11,674.9 compared to 3768.4 per 100,000 population) [6]. More specifically, the incidence of ischaemic heart disease has increased, especially since 2012 . The incidence during 2012-2017 increased from 651.25 to 1536.46 per 100,000 population (Fig. 2) [24]. The number of newly registered cases of respiratory diseases has varied from its lowest in 2001 to its highest in 2017 (from 20,143.6 to 28,044.1 per 100,000 population) [6]. One of the major diseases associated with smoking is chronic obstructive pulmonary disease. The incidence of this disease has also increased in the last 16 years. For example, in 2001 this indicator was 536.09 and in 2017 it was twice as high, at 1003.23 per 100,000 population (Fig. 2) [24].

Moreover, increasing rates of new cases of cancer per 100,000 population were observed. In 2000 , the rate of malignant neoplasms was 470.6 new cases per 100,000 population and has reached 1048 new cases per 100,000 population. In general, the number of new cases of tumours has increased more than two-fold in a period of 17 years. The incidence of cancer of the trachea, bronchus, and lung increased by $10 \%$, from 54.8 persons with tumours per 100,000 population in 2000 to 64 persons with tumours per 100,000 population in 2017 [6]. However, these were total numbers of cases of the diseases. In order to evaluate real burden of smoking, the smoking-attributable fraction (SAF) should be used in calculations.

It is worth mentioning that smoking also has a significant negative impact on the economy. Despite the taxes levied on the sale of tobacco products, health care costs of treatment of smoking-related diseases are much

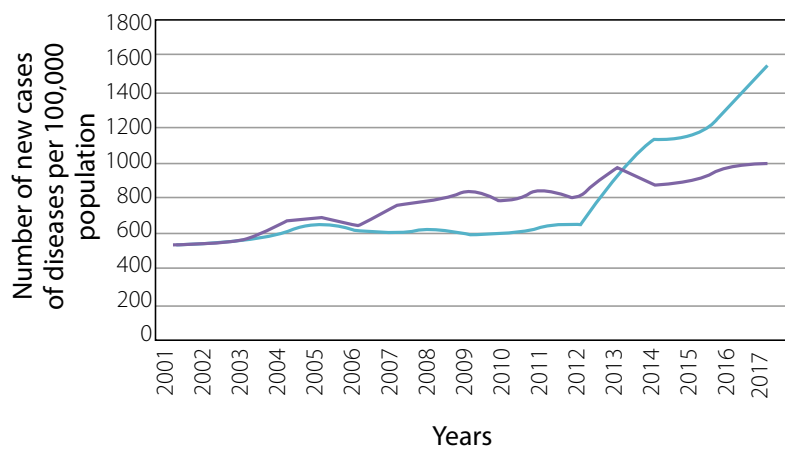

— Incidence of ischemic heart disease at age of 18 or older

— Incidence of chronic obstructive pulmonary disease at age of 18 or older

FIG. 2. Incidence of ischaemic heart disease and chronic obstructive pulmonary disease at the age of 18 years or older in Lithuania in 2001-2017 [24] 
higher. In Lithuania the total direct healthcare smoking-attributable government expenditure was 37.4 million euro in 2013. This represented 3\% of the total Compulsory Health Insurance Fund budget in 2013 [25]. According to Goodchild, estimated public health expenditures on SADs in 2009 were 46 million euro, 3.11\% of total healthcare spending. In the same year monetary loss from premature mortality due to smoking was 3.466 million euro, $8.11 \%$ of Lithuania's GDP [26].

\section{CONCLUSIONS}

In recent years science-based measures such as special labelling, an advertising ban, and increased taxes have been adopted in Lithuania. Furthermore, measures such as expanded non-smoking areas and plain packaging are under consideration. However, legislative changes alone are not enough. A reshaping of public attitudes towards tobacco use is necessary. In addition, it is important to continue to conduct comprehensive studies in order to assess the health damage caused by tobacco products and its economic impact on the health care sector.

\section{ACKNOWLEDGEMENTS}

Authors would like to thank Mindaugas Štelemèkas for his comments on this article.

\section{DISCLOSURE}

The authors report no conflict of interest.

\section{References}

1. Lithuanian Law on Tobacco Control. Lithuanian Parliament, 1995. Available from: https://www.e-tar.lt/portal/legalAct. html? documentId=TAR.F8090E375DA0 (accessed: 14 Jan 2019).

2. Ruling of the Constitutional Court of the Republic of Lithuania, Case No. 696 - 1096, 13 February 1997, Vilnius. The Constitutional Court of the Republic of Lithuania, 1997.

3. Grabauskas V, Klumbienė J, Petkevičienė J, et al. Health behaviour among Lithuanian adult population, 2014. Lithuanian University of Health Sciences, Kaunas 2015.

4. European School Survey Project on Alcohol and Other Drugs (ESPAD), Pompidou Group, Council of Europe, Swedish Council for Information on Alcohol and Other Drugs (CAN). ESPAD Report 1995: Alcohol and Other Drug Use Among Students in 26 European Countries. Swedish Council for Information on Alcohol and Other Drugs (CAN), Stockholm, Sweden 1997. Available from: http://www.espad.org/sites/espad.org/ files/The_1995_ESPAD_report.pdf (accessed: 14 Jan 2019).

5. Lithuanian Law on Tobacco Control, amendments. 2003. Available from: https://e-seimas.lrs.lt/portal/legalAct/lt/TAD/ TAIS.223448 (accessed: 14 Jan 2019).

6. Statistics Lithuania. Available from: https://osp.stat.gov.lt (accessed: 14 Jan 2019).

7. Lithuanian Law on Control of Tobacco, Tobacco Products and Related Products, Amendments. Lithuanian Parliament, 2006.
Available from: https://e-seimas.lrs.lt/portal/legalAct/lt/TAD/ TAIS.276528 (accessed: 14 Jan 2019).

8. Klumbiene J, Sakyte E, Petkeviciene J, et al. The effect of tobacco control policy on smoking cessation in relation to gender, age and education in Lithuania, 1994-2010. BMC Public Health 2015; 15: 181.

9. Special Eurobarometer 429 "Attitudes of Europeans towards Tobacco and Electronic Cigarettes". European Union 2015; 214.

10. Special Eurobarometer 458 "Attitudes of Europeans towards tobacco and electronic cigarettes". European Union 2017; 205.

11. Directive 2014/40/EU on the approximation of the laws, regulations and administrative provisions of the Member States concerning the manufacture, presentation and sale of tobacco and related products and repealing Directive 2001/37/ EC. Europian Parliament and Council, 2014. Available from: https://publications.europa.eu/en/publication-detail/-/publication/025cab37-e4fd-43da-b4f8-7183ccf0f1b6/language-en (accessed: 14 Jan 2019).

12. Lithuanian Law on Control of Tobacco, Tobacco Products and Related Products, Amendments. Lithuanian Parliament, 2014. Available from: https:/e-seimas.lrs.lt/portal/legalAct/lt/TAD/ b8d8f64090e311e48028e9b85331c55d (accessed: 14 Jan 2019).

13. European Code Against Cancer - 12 ways. Available from: https://cancer-code-europe.iarc.fr/index.php/en/ecac-12-ways (accessed: 14 Jan 2019).

14. Lithuanian Law on Control of Tobacco, Tobacco Products and Related Products, Amendments 2015. Available from: https:// e-seimas.lrs.lt/portal/legalAct/lt/TAD/76517290d93911e4b18a86d1db8d4222 (accessed: 14 Jan 2019).

15. The ESPAD Group. ESPAD Report 2015. Results from the European School Survey Project on Alcohol and Other Drugs. Publications Office of the European Union, Luxembourg 2016. Available from: http://www.espad.org/sites/espad.org/files/ ESPAD_report_2015.pdf (accessed: 14 Jan 2019).

16. Hibell B, Centralförbundet för alkohol- och narkotikaupplysning, European School Survey Project on Alcohol and Other Drugs. The ESPAD report 2003: alcohol and other drug use among students in 35 European countries. Swedish Council for Information on Alcohol and Other Drugs (Centralförb. för alkohol- och narkotikaupplysning) (CAN), Stockholm 2004. Available from: http://www.espad.org/content/espad-report2003-alcohool-and-other-drug-use-among-students-35-european-countries (accessed: 14 Jan 2019).

17. Hibell B, Stergar E, Dernovšček Hafner N (eds.). The 2011 ESPAD Report: substance use among students in 36 European countries. Stockholm: The Swedish Council for Information on Alcohol and Other Drugs (CAN); 2012. Available from: http://www.espad.org/sites/espad.org/files/The_2011_ESPAD_ Report_FULL_2012_10_29.pdf (accessed: 14 Jan 2019).

18. Hibell B. The 2007 ESPAD report: substance use among students in 35 European countries. The Swedish Council for Information on Alcohol and other Drugs, Stockholm 2009. Available from: http://www.espad.org/sites/espad.org/files/The_2007_ ESPAD_Report-FULL_091006.pdf (accessed: 14 Jan 2019).

19. Drug, Tobacco and Alcohol Control Department. Annual Report, 2018, p. 120. Available from: http://ntakd.lrv.lt/ 
uploads/ntakd/documents/files/NTAKD_ataskaita(1).pdf (accessed: 14 Jan 2019).

20. Results of the Health Interview Survey of the Population of Lithuania 2014. Statistics Lithuania, Vilnius 2015. Available from: https://www.stat.gov.lt/en/home/-/asset_publisher/lbrXvLVHX2ln/content/id/3794856 (accessed: 14 Jan 2019).

21. Inchley J, Currie D, Young T, et al. (eds.). Growing up unequal: gender and socioeconomic differences in young people's health and well-being: Health Behaviour in School-Aged Children (HBSC) Study: international report from the 2013/2014 survey. World Health Organization Regional Office for Europe, Copenhagen, Denmark 2016; 276 (Health policy for children and adolescents). Available from:http://www.euro.who.int/_ data/assets/pdf_file/0003/303438/HSBC-No.7-Growing-upunequal-Full-Report.pdf (accessed: 14 Jan 2019).

22. King AJC (ed.). The health of youth: a cross-national survey. WHO Regional Office for Europe, Copenhagen, Denmark 1996; 222 (WHO regional publications). Available from: https://files.eric.ed.gov/fulltext/ED400062.pdf (accessed: 14 Jan 2019).

23. Liutkute V, Veryga A, Štelemèkas M, et al. Burden of smoking in Lithuania: attributable mortality and years of potential life lost. Eur J Public Health 2017; 27: 736-741.

24. The Health Indicators of Lithuania - Higienos institutas. Available from: http://www.hi.lt/en/the-health-indicators-of-lithuania.html (accessed: 14 Jan 2019).

25. Liutkutė V, Štelemèkas M, Veryga A. Smoking-attributable direct healthcare expenditure in Lithuania: A prevalence-based annual cost approach. Medicina (Kaunas). 2018 May; 54: 15.

26. DHK. A study on liability and the health costs of smoking DG SANCO (2008/C6/046),2012. Final Report.GHK, London 2012. Available from: https://ec.europa.eu/health/sites/health/files/ tobacco/docs/tobacco_liability_final_en.pdf (accessed: 14 Jan 2019).

\section{AUTHORS' CONTRIBUTIONS}

LM and JV prepared the research concept and design, collected data, wrote the article, revised the article and finally approved it. 